NASA Technical Memorandum 106562 AIAA-94-3078
Army Research Laboratory Technical Report ARL-TR-401

\title{
Surface Fatigue Life of High Temperature Gear Materials
}

Dennis P. Townsend

National Aeronautics and Space Administration

Lewis Research Center

Cleveland, Ohio

Prepared for the

30th Joint Propulsion Conference

cosponsored by the AIAA, ASME, SAE, and ASEE

Indianapolis, Indiana, June 27-29, 1994

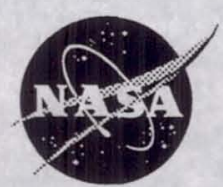

National Aeronautics and

Space Administration

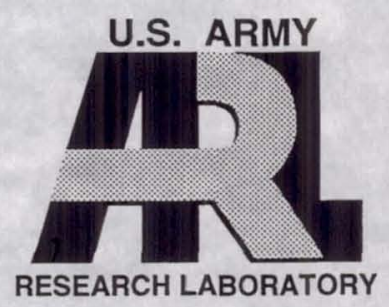




\title{
SURFACE FATIGUE LIFE OF HIGH TEMPERATURE GEAR MATERIALS
}

\author{
Dennis P. Townsend \\ National Aeronautics and Space Administration \\ Lewis Research Center \\ Cleveland, Ohio 44135
}

\begin{abstract}
$\underline{\text { Abstract }}$
Three high temperature gear materials were evaluated using spur gear surface fatigue tests. These materials were, VASCO max 350 , VASCO matrix $\mathrm{I}$, and nitralloy $\mathrm{N}$ and were evaluated for possible use in high temperature gear applications. The fatigue life of the three high temperature gear materials were compared with the life of the standard AISI 9310 aircraft gear material. Surface fatigue tests were conducted at a lubricant inlet temperature of $321 \mathrm{~K}$ $\left(120^{\circ} \mathrm{F}\right)$, a lubricant outlet temperature of $350 \mathrm{~K}\left(170^{\circ} \mathrm{F}\right)$, a maximum Hertz stress of $1.71 \mathrm{GPa}(248 \mathrm{ksi})$, a speed of $10000 \mathrm{rpm}$ and with a synthetic paraffinic lubricant. The life of the nitralloy $\mathrm{N}$ was approximately the same as the AISI 9310 , the life of the VASCO max 350 was much less than the AISI 9310 while the life of the VASCO matrix II was several times the life of the AISI 9310. The VASCO $\max 350$ also showed very low fracture toughness with approximately half of the gears failed by tooth fracture through the fatigue spall. The VASCO matrix II had approximately 10-percent fracture failure through the fatigue spalls indicating moderate to good fracture toughness.
\end{abstract}

\section{Introduction}

Aircraft turbine engine requirements are increasing the demand for higher operating temperature in several advanced and high power density applications for gears and rolling element bearings. The surface temperature of power gearing normally operates considerably higher than the bulk oil temperature; thereby, requiring a more temperature resistant gear material that will provide long life at these high temperature operating conditions. Previous testing with rolling element bearings ${ }^{1}$ has shown that at high stress loads the surface fatigue life of bearings is much longer when the surface hardness at the operating temperature is Rockwell Rc 58 or higher and is drastically reduced when the hardness is less than Rc 58.

Several high-hot hardness carburized grade steels have been developed for bearing and gearing in recent years. Bearing and rolling contact fatigue tests have shown very good surface fatigue life with some of these new high temperature materials. $^{2}$

Hot hardness testing of several high temperature steels were conducted ${ }^{3,4}$ to determine their short term and long term hot hardness and their potential for use as high temper- ature bearing and gear steels. High temperature gear tests have been conducted with several gear materials. ${ }^{5,6}$ Two nitriding materials that have shown promise for moderate to high temperatures were nitralloy $\mathrm{N}$ and super nitralloy (5Ni2Al). Nitralloy $\mathrm{N}$ was used ${ }^{7}$ to conduct scoring tests up to $644 \mathrm{~K}\left(700^{\circ} \mathrm{F}\right)$ with a bulk oil temperature of $477 \mathrm{~K}$ $\left(400{ }^{\circ} \mathrm{F}\right)$. The hot hardness tests with super nitralloy, $5 \mathrm{Ni} 2 \mathrm{Al},{ }^{3}$ have shown that it maintains a usable hot hardness up to $505 \mathrm{~K}\left(450^{\circ} \mathrm{F}\right)$. Nitralloy $\mathrm{N}$ would be expected to have a hot hardness a little lower than super nitralloy since it has 1.5 percent less nickel. Fatigue tests were conducted with gears manufactured from super nitralloy, $5 \mathrm{Ni} 2 \mathrm{Al},{ }^{8}$ which showed a fatigue life that was comparable to AISI 9310.

Hot hardness testing with VASCO matrix $\mathrm{II}^{3}$ shows that it maintains a usable hot hardness in excess of $644 \mathrm{~K}$ $\left(700^{\circ} \mathrm{F}\right)$. This material is through hardened similar to high strength tool steels such as AISI M-50. VASCO matrix II is an age hardening high temperature material that is aged at $769 \mathrm{~K}\left(925^{\circ} \mathrm{F}\right)$ to have a hardness of Rc 60 through precipitation hardening in a martensite matrix structure.

Rolling contact tests were conducted in a RC (rolling contact) machine ${ }^{2}$ with VASCO matrix II and VASCO max 350 . In these tests the VASCO matrix II had rolling contact fatigue life equivalent to M50 while the VASCO Max 350 Rc fatigue life was considerably less.

The objective of the research work reported in this paper was to compare under closely controlled test conditions the fatigue lives and failing modes of test spur gears made of nitralloy N, VASCO max 350, and VASCO matrix II and compare the results with the standard aircraft gear material AISI 9310.

\section{Test Gears and Materials}

The test gears used in the tests reported herein are shown in Fig. 1. Dimensions for the test gears are summarized in Table 1. All gears had a minimal surface finish on the tooth flank of $0.406 \mu \mathrm{m}$ cla (16 $\mu$ in. cla) and a standard $20^{\circ}$ involute tooth profile with a small profile tip relief.

The test gears were manufactured from three materials. These were consumable electrode vacuum melted (CVM) VASCO max 350, CVM VASCO matrix II, and nitralloy N AMS $6475 \mathrm{D}$. The test results were compared with gears 
manufactured from CVM AISI 9310 AMS 6265H. The chemical composition of these materials are given in Table 2.

The gears manufactured from the nitralloy $\mathrm{N}$ material were case nitrided and hardened to a Rockwell hardness of Rc 63 with a case depth of 0.046 to $0.051 \mathrm{~cm}(0.018$ to 0.020 in.) and with a core hardness of Rockwell Rc 41. Photomicrographs of the case and core of the nitralloy $\mathrm{N}$ gears are shown in Figs. 2(a) and (b).

The VASCO max 350 gears were finish machined to allow for $25 \times 10^{-4} \mathrm{~cm}(0.001 \mathrm{in}$.) shrinkage during age hardening. They were then age hardened at 760 to $777 \mathrm{~K}(910$ to $940{ }^{\circ} \mathrm{F}$ ) for $3 \mathrm{hr}$ and allowed to air cool for a case hardness of Rockwell Rc 59 and a core hardness of Rockwell Rc 57.5. Photomicrographs of the case and core of the VASCO max 350 are shown in Figs. 2(c) and (d).

The gears manufactured from VASCO matrix II were hardened after rough machining by austenetizing at 1380 to $1390 \mathrm{~K}$ (2020 to $2040^{\circ} \mathrm{F}$ ) for $15 \mathrm{~min}$, quench in a salt bath at $880 \mathrm{~K}\left(1125^{\circ} \mathrm{F}\right)$ and air cool to room temperature. They were then triple tempered $(2+2+2 \mathrm{hr})$ at 811 to $825 \mathrm{~K}$ $\left(1000\right.$ to $\left.1025^{\circ} \mathrm{F}\right)$ as soon as the steel had cooled to 311 to $339 \mathrm{~K}\left(100\right.$ to $\left.150^{\circ} \mathrm{F}\right)$ from the quench. Photomicrographs of the case and core of the VASCO matrix II are shown in Figs. 2(e) and (f).

The gear pitch diameter was $8.89 \mathrm{~cm}$ (3.5 in.). Table 3 lists the heat treatment procedure for the different groups of gears tested including AISI 9310. Each group of gears was tested to fatigue failure by surface pitting under identical test conditions. These test conditions included a gear temperature of $350 \mathrm{~K}\left(170^{\circ} \mathrm{F}\right)$, a maximum Hertz stress of $1.71 \mathrm{GPa}(248 \mathrm{ksi})$, and a speed of $10000 \mathrm{rpm}$.

\section{Apparatus and Procedure}

\section{Gear Test Apparatus}

The gear fatigue tests were performed in the NASA Lewis Research Center's gear test apparatus (Fig. 3(a)). This test rig used the four-square principle of applying the test gear load so that the input drive only needs to overcome the frictional losses in the system.

A schematic of the test rig is shown in Fig. 3(b). Oil pressure and leakage flow are supplied to the load vanes through a shaft seal. As the oil pressure is increased on the load vanes inside the slave gear, the loop torque is applied. This torque is transmitted through the test gears back to the slave gear, where an equal but opposite torque is maintained by the oil pressure. This torque on the test gears, which depends on the hydraulic pressure applied to the load vanes, loads the gear teeth to the desired contact or Hertz stress level. The two identical test gears can be started under no load, and the load can be applied gradually, without changing the running track on the gear teeth.

Separate lubrication systems are provided for the test gears and the main gearbox. The two lubrication systems are separated at the gearbox shafts by pressurized labyrinth seals. Nitrogen is the seal gas. The test gear lubricant is filtered through a $5-\mu \mathrm{m}$-nominal fiberglass filter. The test lubricant can be heated electrically with an immersion heater. The temperature of the heater is controlled to prevent overheating the test lubricant.

A vibration transducer mounted on the gearbox is used to automatically shut off the test rig when a gear surface fatigue occurs. The gearbox is also automatically shut off if there is a loss of oil flow to either the main gearbox or the test gears, if the test gear oil overheats, or if there is a loss of seal gas pressurization.

The belt-driven test rig can be operated at several fixed speeds by changing pulleys. The operating speed for the test reported herein was $10000 \mathrm{rpm}$.

\section{Test Lubricant}

All the gears were lubricated with a single bath of synthetic paraffinic oil. The physical properties of this lubricant are summarized in Table 4. Five percent of an extreme-pressure additive, designated Lubrizol 5002 (partial chemical analysis given in Table 4), was added to the lubricant.

\section{Test Procedure}

After the test gears were cleaned to remove the preservative, they were assembled on the test rig. The $0.635-\mathrm{cm}(0.25$-in.) wide test gears were run in an offset condition with a $0.30-\mathrm{cm}(0.12$-in.) tooth-surface overlap to give a load surface on the gear face of $0.28 \mathrm{~cm}(0.11 \mathrm{in}$.), thereby allowing for the edge radius of the gear teeth. If both faces of the gears were tested, four fatigue tests could be run for each set of gears. The gear tooth test temperature was low enough to prevent one test from affecting the other test with the same gear. All tests were run in at a pitch-line load of $1225 \mathrm{~N} / \mathrm{cm}(700 \mathrm{lb} / \mathrm{in}$.) for $1 \mathrm{hr}$, which gave a maximum Hertz stress of $0.756 \mathrm{GPa}(111 \mathrm{ksi})$. The load was then increased to $5784 \mathrm{~N} / \mathrm{cm}$ (3305 lb/in.), which gave a pitch-line maximum Hertz stress of $1.71 \mathrm{GPa}$ (248 ksi) if plain bending is assumed. However, because there was an offset load, an additional stress was imposed on the tooth bending stress. Combining the bending and torsional moments gave a maximum stress of $0.26 \mathrm{GPa}$ ( $37 \mathrm{ksi}$ ). This bending stress does not include the effects of tip relief, which would also increase the bending stress.

Operating the test gears at $10000 \mathrm{rpm}$ gave a pitch-line velocity of $46.55 \mathrm{~m} / \mathrm{sec}$ (9163 ft/min). Lubricant was 
supplied to the inlet mesh at $800 \mathrm{~cm}^{3} / \mathrm{min}(0.21 \mathrm{gpm})$ at $321 \mathrm{~K}\left(120^{\circ} \mathrm{F}\right)$ The lubricant outlet temperature was nearly constant at $350 \mathrm{~K}\left(170{ }^{\circ} \mathrm{F}\right)$. The tests ran continuously (24 hr/day) until they were automatically shut down by the vibration detection transducer, located on the gearbox adjacent to the test gears. The lubricant circulated through a 5-m fiberglass filter to remove wear particles. After each test the lubricant and the filter element were discarded. Inlet and outlet oil temperatures were continuously recorded on a strip-chart recorder.

The pitch-line elastohydrodynamic (EHD) film thickness was calculated by the method of Ref. 9. It was assumed, for this film thickness calculation, that the gear temperature at the pitch line was equal to the outlet oil temperature and that the inlet oil temperature to the contact zone was equal to the gear temperature, even though the inlet oil temperature was considerably lower. It is possible that the gear surface temperature was even higher than the outlet oil temperature, especially at the end points of sliding contact. The EHD film thickness for these conditions was computed to be $0.33 \mu \mathrm{m}$ (13 $\mu \mathrm{in}$.), which gave an initial ratio of film thickness to composite surface roughness, $\lambda$ of 0.55 at the $1.71 \mathrm{GPa}$ (248 ksi) pitch-line maximum Hertz stress.

\section{$\underline{\text { Results and Discussion }}$}

One lot each of CVM VASCO max 350, VASCO matrix II, and nitralloy $\mathrm{N}$ spur gears were tested in pairs until failure or were suspended after $500 \mathrm{hr}$ of testing without failure. Twenty or more gears were tested in each lot. Test conditions were a tangential load of $6364 \mathrm{~N} / \mathrm{cm}$ (3634 lb/in.), which produced a maximum Hertz stress of $1.71 \mathrm{GPa}$, (248 ksi). The test gears failed either by pitting and or tooth fracture. Test results were analyzed by considering the life of each pair of gears as a system. The pitting fatigue life results of these tests are shown using the Weibull plots of Fig. 4 and are summarized in Table 5. These data were analyzed by the method of Johnson. ${ }^{10}$

A Weibull plot of the surface-pitting fatigue life of the CVM VASCO max 350 gears is shown in Fig. 4(a). A typical fatigue spall is shown in Fig. 5(a). Several of the VASCO max 350 gears failed by tooth fracture either before or after a fatigue spall. A typical tooth fracture for these gears is shown in Fig. 6(a). The tooth fractures that failed after a fatigue spall were treated as surface fatigue failures while those that failed without a fatigue spall were treated as suspensions. There were two tests that ran for $500 \mathrm{hr}$ without failure and these were also treated as suspensions. The 10- and 50-percent surface fatigue lives of the VASCO $\max 350$ test gears are shown in the Weibull plot of Fig. 4(a) and Table 5 and was 2 million and 15 million stress cycles, respectively. These lives are considerably less than the standard AISI 9310 test gears which have a 10- and 50 -percent surface fatigue of 20 million and 45 million cycles respectively. The confidence number for the life difference between the VASCO max 350 and AISI 9310 was 99 percent which indicates that the life difference is statistically significant. The confidence number indicates the percentage of time the order of the test results would be the same. For a confidence number of 99 percent, 99 out of 100 times the test is repeated the gear life difference for the two materials would be the same. Experience has shown that a confidence number of 80 percent or greater would indicate a meaningful life difference.

A Weibull plot of the surface pitting fatigue life of the VASCO matrix II gears is shown in Fig. 4(b). There were 33 fatigue tests run with this material, 11 of which ran for $500 \mathrm{hr}$ without failure. A fatigue spall for this material is shown in Fig. 5(b). There were two gear tests that resulted in broken teeth for this material after running for some time with a fatigue spall. Figure 6(b) shows a typical tooth fracture through the fatigue spall for this material. The 10- and 50-percent surface fatigue lives of the VASCO matrix II test gears are shown in the Weibull plot in Fig. 4(b) and Table 5 and were 141 million and 287 million stress cycles, respectively. These lives were approximately 7 times the life of the standard AISI 9310 gears and more than 20 times the life of the VASCO $\max 350$. The confidence number for the life difference between the VASCO matrix II and the AISI 9310 was 99 percent which indicates that the life difference is statistically significant.

The surface pitting fatigue life of the nitralloy N (AMS 6475D) is shown in the Weibull plot of Fig. 4(c). A typical fatigue for these gears is shown in Fig. 5(c). There were 23 surface fatigue tests conducted with the nitralloy $\mathrm{N}$ gears all of which resulted in surface fatigue spalls. The 10- and 50percent surface fatigue lives of the nitralloy $\mathrm{N}$ are shown in the Weibull plot of Fig. 4(c) and Table 5 and was 19 million and 39 million stress cycles, respectively. The surface fatigue life of the nitralloy $\mathrm{N}$ was only slightly less than the life of the AISI 9310 and would be statistically equal to the life of the AISI 9310 gears. The confidence number for the life difference between the nitralloy $\mathrm{N}$ and AISI 9310 was 50 percent which means that the life difference is not statistically significant.

\section{$\underline{\text { Summary of Results }}$}

Three groups of carburized, hardened, and ground spur gears manufactured from one heat each of CVM VASCO max 350, CVM VASCO matrix II, and nitralloy N (AMS $6475 \mathrm{D}$ ) were evaluated using spur gear surface fatigue tests. These materials were evaluated for possible use in high temperature gear applications and were compared with one group of the standard aircraft gear material CVM AISI 9310 AMS $6265 \mathrm{H}$.

Surface fatigue tests were conducted at a lubricant inlet temperature of $321 \mathrm{~K}\left(120^{\circ} \mathrm{F}\right)$, a lubricant outlet 
temperature of $350 \mathrm{~K}\left(170^{\circ} \mathrm{F}\right)$, a maximum Hertz stress of $1.71 \mathrm{GPa}$, a speed of $10000 \mathrm{rpm}$ and with a synthetic paraffinic lubricant. The following results were obtained.

1. The 10-percent life of the nitralloy $\mathrm{N}$ was approximately the same as the AISI 9310.

2. The 10-percent life of the VASCO $\max 350$ was approximately one-tenth of the life of the standard AISI 9310.

3. The 10-percent life of the VASCO matrix II was approximately seven times the life of the standard AISI 9310.

4. The VASCO $\max 350$ demonstrated very low fracture toughness with approximately one-half of the gears failing by tooth fracture through a fatigue spall.

5. The VASCO matrix II had approximately 10 -percent fracture failure through a fatigue spall indicating moderate to good fracture toughness.

\section{$\underline{\text { References }}$}

${ }^{1}$ Anderson, W.J. and Zaretsky, E.V., "Rolling-Element Bearings," Machine Design, Vol. 18, June 1968, pp. 22-39.

${ }^{2}$ Nahm, A.H., "Rolling Element Fatigue Testing of Gear Materials," Final Report NASA CR-135450, June 26, 1978.

${ }^{3}$ Chevalier, J.L., Dietrich, M.W., and Zaretsky, E.V., "Hot Hardness Characteristics of Ausforged AISI M-50,

\section{TABLE 1.-SPUR GEAR DATA}

[Gear tolerance per AGMA class 12.]

\begin{tabular}{|c|}
\hline \\
\hline$\ldots \ldots \ldots \ldots \ldots \ldots \ldots$ \\
\hline rcular pitch, cm (in.) $\ldots \ldots \ldots \ldots \ldots \ldots \ldots . .9975$ (0.3297) \\
\hline hole depth, $\mathrm{cm}$ (in.) $\ldots \ldots \ldots \ldots \ldots \ldots \ldots \ldots \ldots .762(0.300)$ \\
\hline$\ldots \ldots \ldots 0.3$ \\
\hline ckness (reference), $\mathrm{cm}$ (in.) ... \\
\hline (in.) $\ldots \ldots \ldots \ldots \ldots \ldots \ldots$ \\
\hline$\cdots \cdots \cdots \cdots$ \\
\hline$\ldots \ldots 8$. \\
\hline$m$ (in.) $\ldots \ldots \ldots \ldots$ \\
\hline$\ldots \ldots \ldots \ldots 0.102$ to $0.152(C$ \\
\hline $\begin{array}{r}\text { er pins, } \mathrm{cm} \text { (in.) } \quad \ldots \ldots \ldots \ldots \ldots \ldots+9.603 \\
(3.7807 \mathrm{t}\end{array}$ \\
\hline ... 0. \\
\hline$\ldots \ldots .0 .0254(0.010)$ \\
\hline $\begin{array}{r}\cdots \\
(0.0004 \text { to } 0.0006)\end{array}$ \\
\hline
\end{tabular}

Matrix II, WD 65, Modified AISI 440C and Super Nitralloy," NASA TN-D7244 May 1973.

${ }^{4}$ Anderson, N.E., and Zaretsky, E.V., "Short Term Hot Hardness Characteristics of Five Case Hardened Steels," NASA TN-D8031, Aug. 1975.

${ }^{5}$ Seabrook, J.B., and Dudley, D.W., "Results of Fifteen Year Program of Flexural Testing of Gear Teeth," Journal of Engineering for Industry, Trans. ASME, Vol. 86, No. 3, Aug. 1964.

${ }^{6}$ Shipley, E.E., "Will Gears Operate at 600 'F?" Am. Machinest, Feb. 1958. pp. 221-239.

${ }^{7}$ Anderson, E.L., and Ku, P.M., "Gear Load Carrying Capacity of Synthetic Lubricants at High Temperature," Proceedings of the USAF-SWRI Turbine Engine Lubrication Conference, (Sept. 13-15, 1966) Feb. 15, 1967. P.M. Ku, ed., pp. 202-211.

${ }^{8}$ Townsend, D.P., Bamberger, E.N. and Zaretsky, E.V., "A Life Study of Ausforged, Standard Forged and Standard Machined AISI M-50 Spur Gears," NASA TM-X71748, ASME Paper 75-LUB-20.

${ }^{9}$ Dowson, D., and Higginson, G.R., ElastoHydrodynamic Lubrication, Pergamon Press, 1966, p. 96.

${ }^{10}$ Johnson, L.G., The Statistical Treatment of Fatigue Experiments, Elsvier, 1964.

TABLE 2.-NOMINAL CHEMICAL COMPOSITION

OF GEAR MATERIALS

\begin{tabular}{|c|c|c|c|c|}
\hline Element & $\begin{array}{l}\text { AISI } \\
9310\end{array}$ & $\begin{array}{l}\text { VASCO } \\
\text { matrix II }\end{array}$ & $\begin{array}{l}\text { VASCO } \\
\max 350 \\
\end{array}$ & Nitralloy $N$ \\
\hline Carbon & 0.1 & 0.51 & 0.01 & 0.24 \\
\hline Nickel & 3.22 & - & 18.5 & 3.5 \\
\hline Chromium & 1.21 & 4.0 & - & 1.18 \\
\hline Molybdenum & 0.12 & 5.0 & 4.8 & 0.25 \\
\hline Cobalt & - & 8.0 & 12.0 & - \\
\hline Manganese & 0.63 & 0.15 & 0.05 & 0.55 \\
\hline Silicon & 0.27 & 0.2 & 0.05 & 0.3 \\
\hline Sulfur & 0.005 & 0.03 & 0.01 & 0.03 \\
\hline Phosphorous & 0.005 & 0.03 & 0.01 & 0.03 \\
\hline Aluminum & - & - & 0.1 & 1.08 \\
\hline Copper & 0.13 & - & - & - \\
\hline Tungsten & - & 1.0 & - & - \\
\hline Vanadium & - & 1.0 & - & - \\
\hline Titanium & - & - & 1.40 & - \\
\hline Boron & - & - & 0.003 & - \\
\hline Calcium & - & - & 0.05 & - \\
\hline Zirconium & - & - & 0.02 & - \\
\hline Iron & Balance & Balance & Balance & Balance \\
\hline
\end{tabular}


TABLE 3.-HEAT TREATMENT FOR TEST GEARS

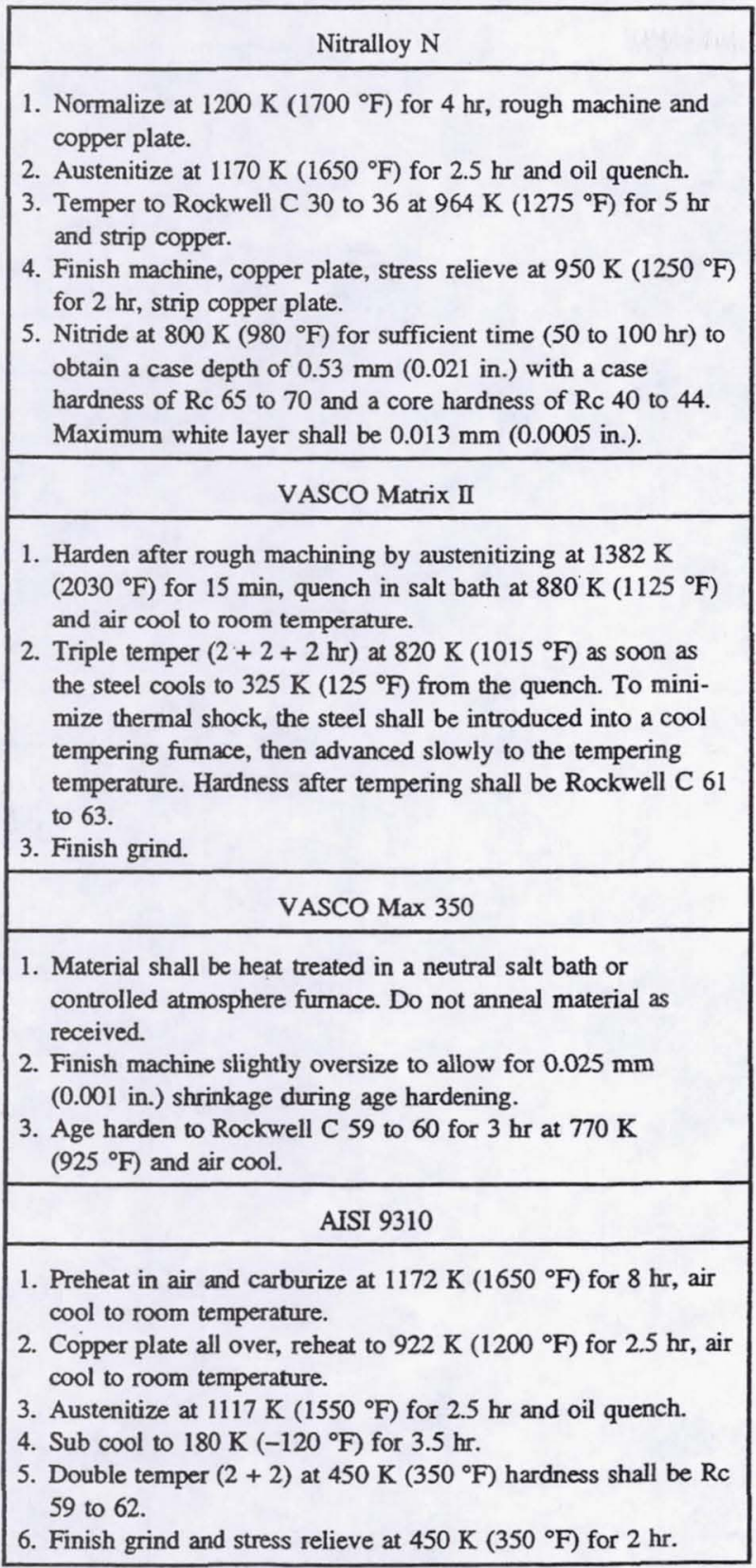

TABLE 4.-PROPERTIES OF SYNTHETIC PARAFFINIC LUBRICANT

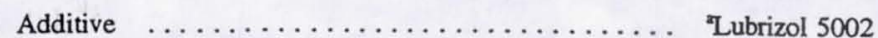

Kinematic viscosity, $\mathrm{cm}^{2} / \mathrm{sec}(\mathrm{cS})$ at-

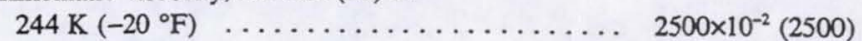

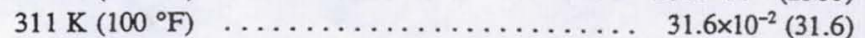

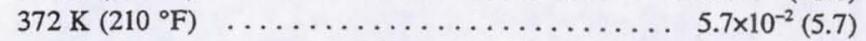

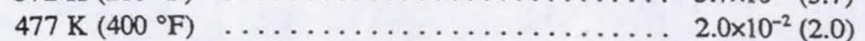

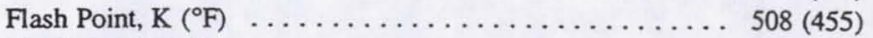

Fire Point, $\mathrm{K}\left({ }^{\circ} \mathrm{F}\right)$. . . . . . . . . . . . . . $533(500)$

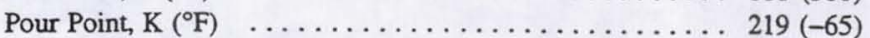

Specific Gravity $\ldots \ldots \ldots \ldots \ldots \ldots \ldots \ldots \ldots \ldots \ldots \ldots \ldots \ldots \ldots \ldots \ldots \ldots \ldots \ldots \ldots . .8285$.

Vapor Pressure at $311 \mathrm{~K}\left(100^{\circ} \mathrm{F}\right), \mathrm{mm} \mathrm{Hg}$ (or torr) $\ldots \ldots \ldots \ldots .1$

Specific Heat at $311 \mathrm{~K}\left(100^{\circ} \mathrm{F}\right) \mathrm{J} / \mathrm{kg} \mathrm{k}\left(\mathrm{Btu} / \mathrm{lb}{ }^{\circ} \mathrm{F}\right) \quad \ldots \ldots 676(0.523)$

aAdditive, Lubrizol 5002 ( 5 vol\%); content of additive: phosphorus, $0.7 \mathrm{wt} \%$; sulphur, 13.4 wt\%.

TABLE 5.-FATIGUE LIFE RESULTS FOR TEST GEARS

\begin{tabular}{|l|c|c|c|c|c|}
\hline \multicolumn{1}{|c|}{ Gears. } & $\begin{array}{c}10 \text {-Percent } \\
\text { life, } \\
\text { cycles }\end{array}$ & $\begin{array}{c}50-\text {-Percent } \\
\text { life, } \\
\text { cycles }\end{array}$ & Slope & $\begin{array}{c}\text { Failure } \\
\text { index }\end{array}$ & $\begin{array}{c}\text { Confidence } \\
\text { number, } \\
\text { percent }\end{array}$ \\
\hline AISI 9310 & $21 \times 10^{6}$ & $45 \times 10^{6}$ & 2.4 & $19 / 20$ & - \\
VASCO matrix II & $141 \times 10^{6}$ & $287 \times 10^{6}$ & 2.6 & $22 / 33$ & 99 \\
VASCO max 350 & $2.1 \times 10^{6}$ & $15.7 \times 10^{6}$ & 0.93 & $20 / 20$ & 99 \\
Nitralloy N & $19 \times 10^{6}$ & $39 \times 10^{6}$ & 2.5 & $23 / 23$ & 50 \\
\hline
\end{tabular}

"Indicates number of failures out of number of test.

'Proability, expressed as a percentage, that the 10-percent life with the baseline AISI 9310 gears is either less than, or greater than, that of the particular lot of gears being considered.

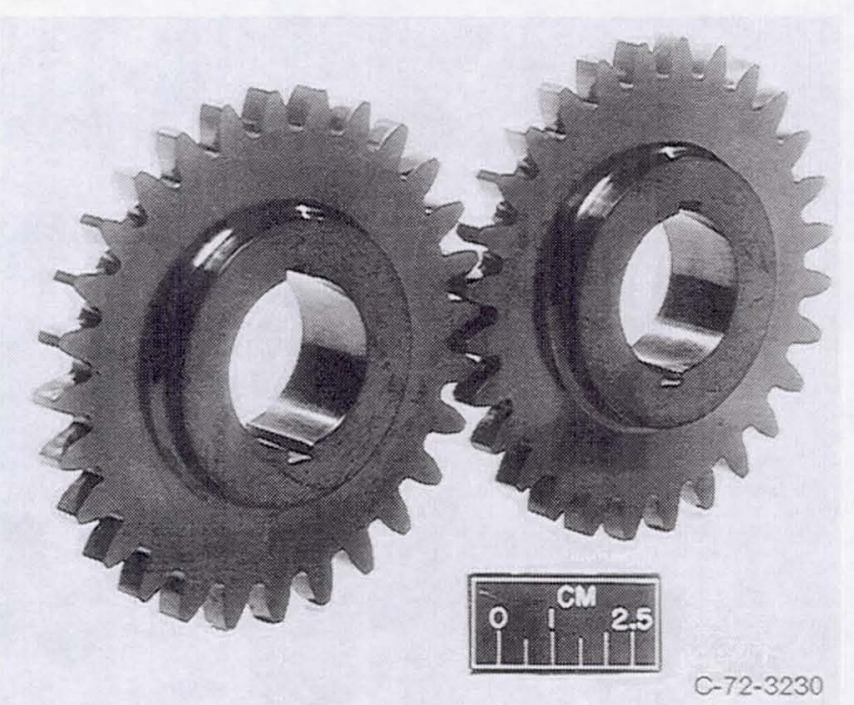



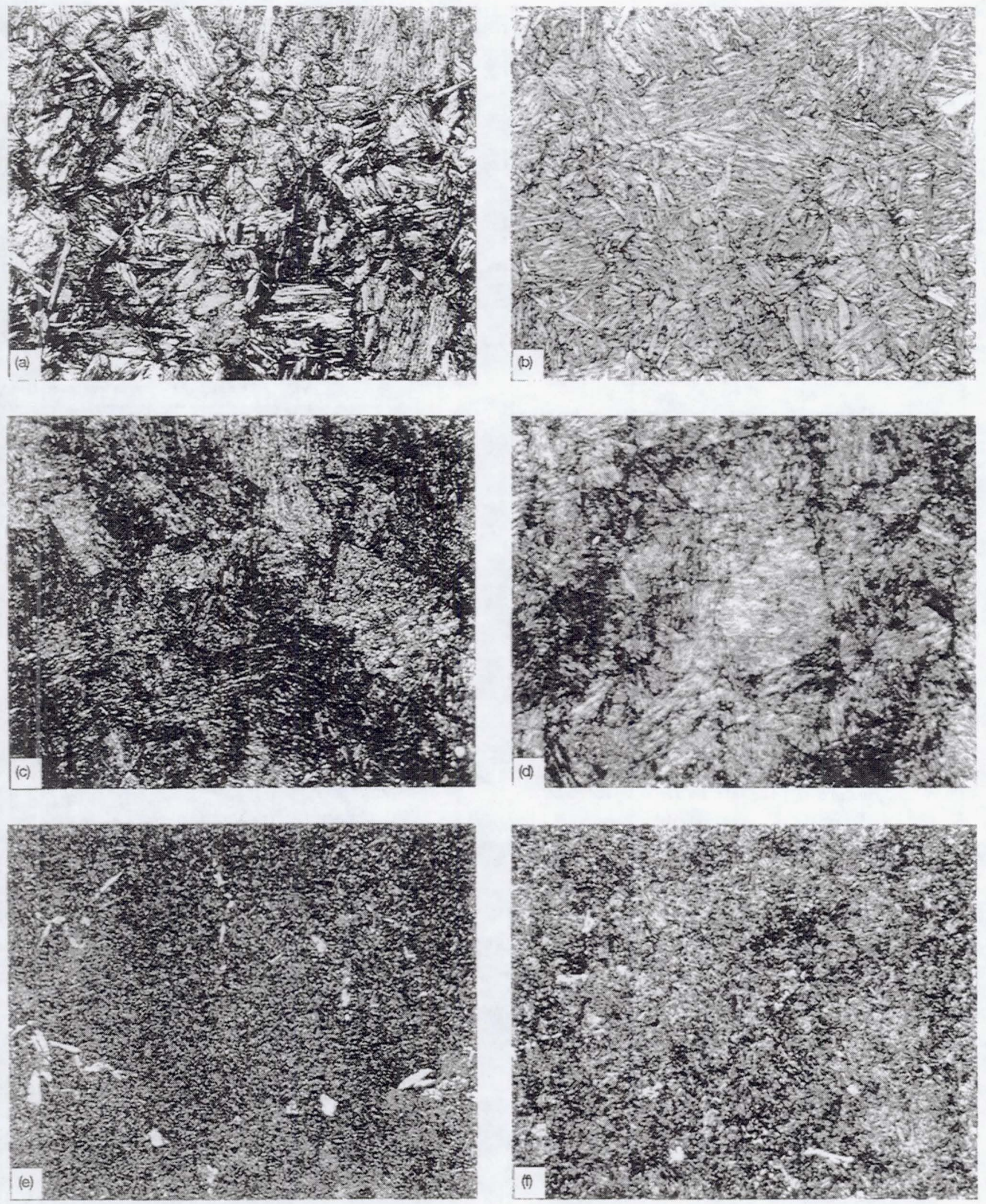

Figure 2.-Photomicrograph of case and core of test gears. (a) Case, (b) core; Nitralloy N. (c) Case, (d) core; VASCO Max 350. (e) Case, (f) core; VASCO Matrix II. 

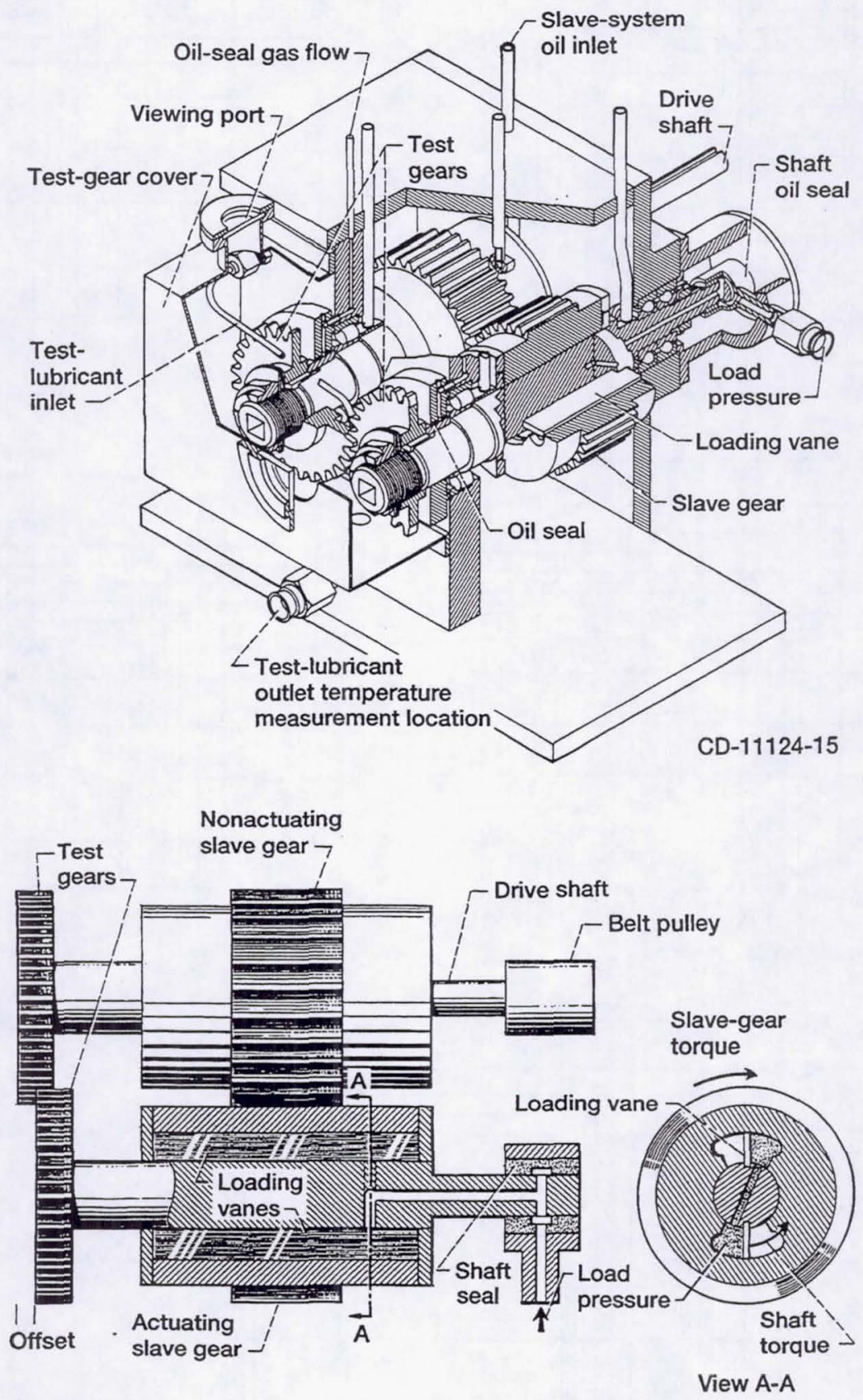

CD-11421-15

Figure 3.-NASA Lewis Research Center's gear-fatigue test machine.

(a) Cutaway view. (b) Schematic diagram. 


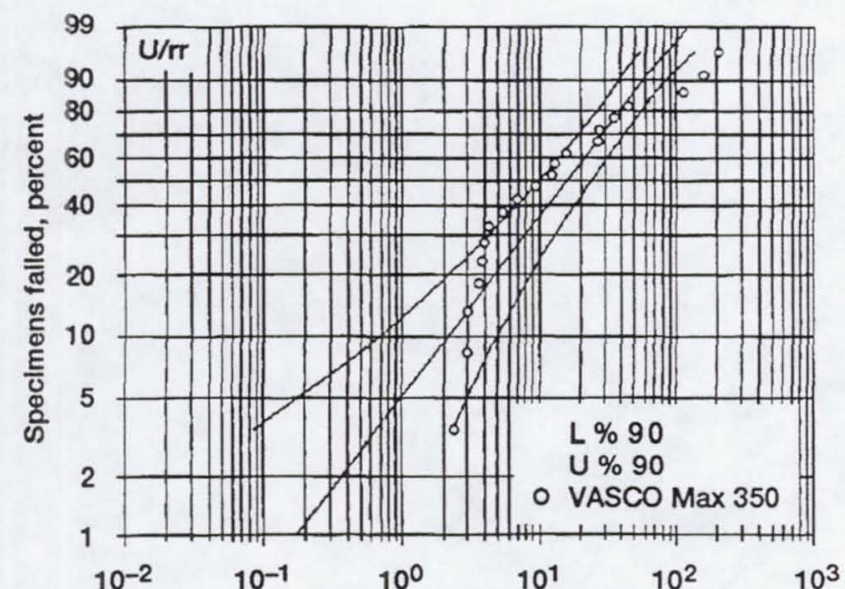

(a)

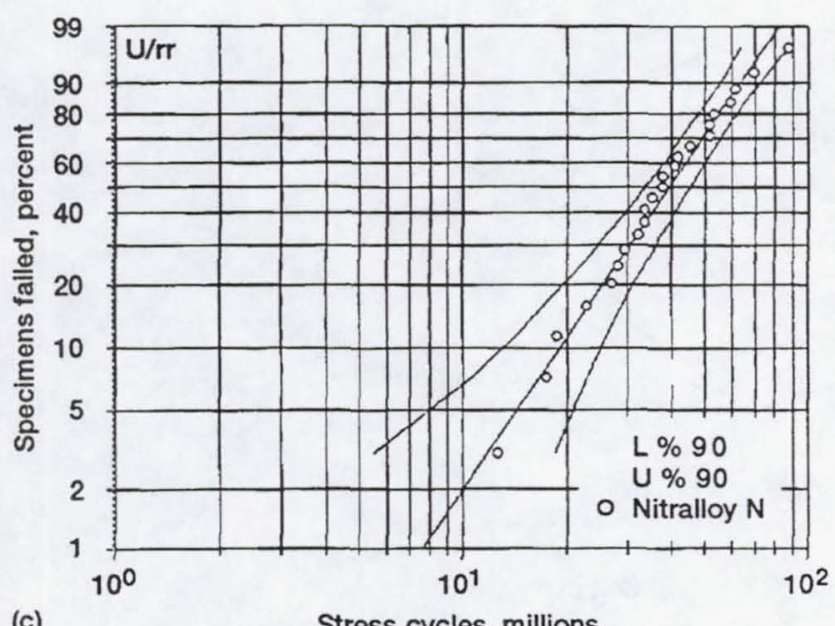

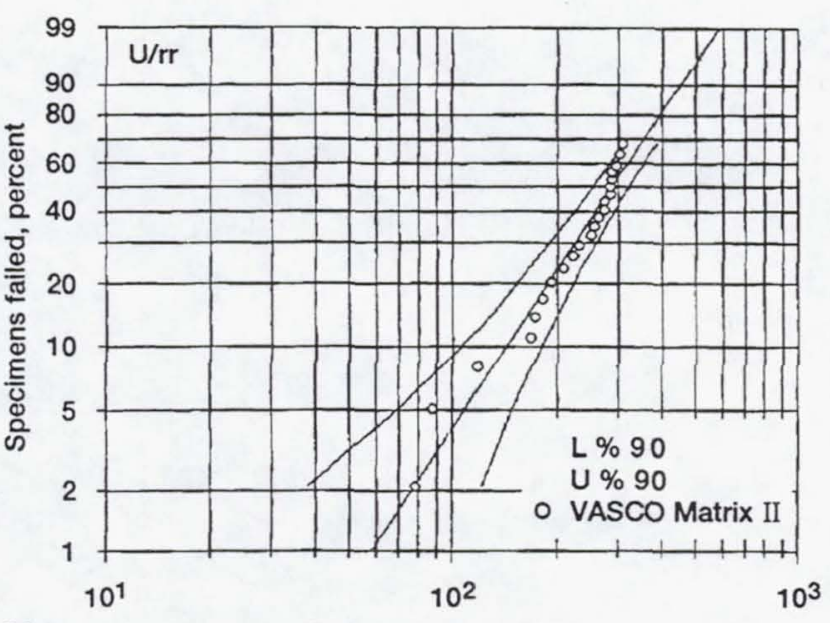

(b)

Stress cycles, millions

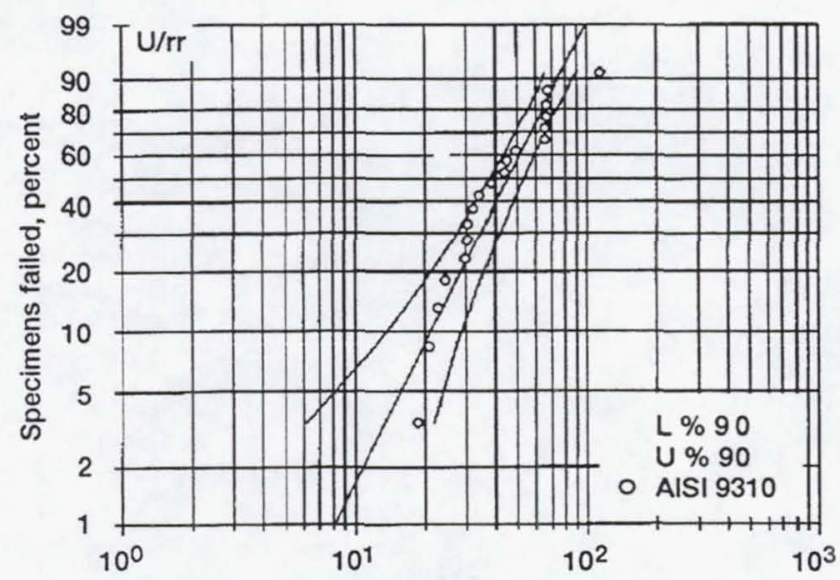

(d)

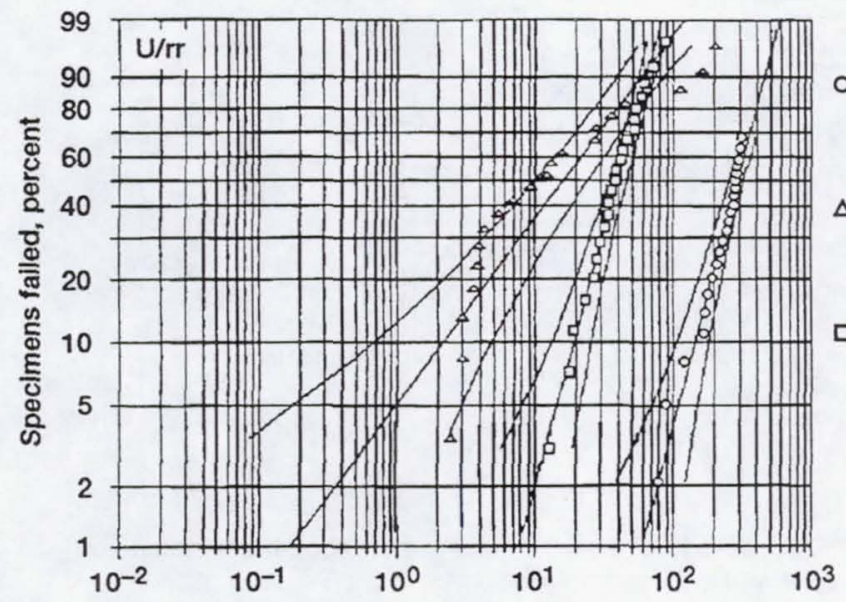

L \% 90

$\mathrm{U} \% 90$

- VASCO Matrix II

L \% 90

$\mathrm{U} \% 90$

$\triangle$ VASCO Max 350

\section{L \% 90 \\ U \% 90 \\ Nitralloy $\mathrm{N}$}

(e)

Stress cycles, millions

Figure 4.-Weibul plots of surface pitting lives of three high temperature gear materials compared with AISI 9310. Pitch diameter $8.39 \mathrm{~cm}$ ( $3.5 \mathrm{in}$.); speed $10000 \mathrm{rpm}$; maximum Hertz stress $1.71 \mathrm{GPa}$ (248 ksi); gear temperature $350 \mathrm{~K}\left(170^{\circ} \mathrm{F}\right)$. (a) VASCO Max 350. (b) VASCO Matrix II. (c) Nitralloy N. (d) AISI 9310. (e) Summary. 

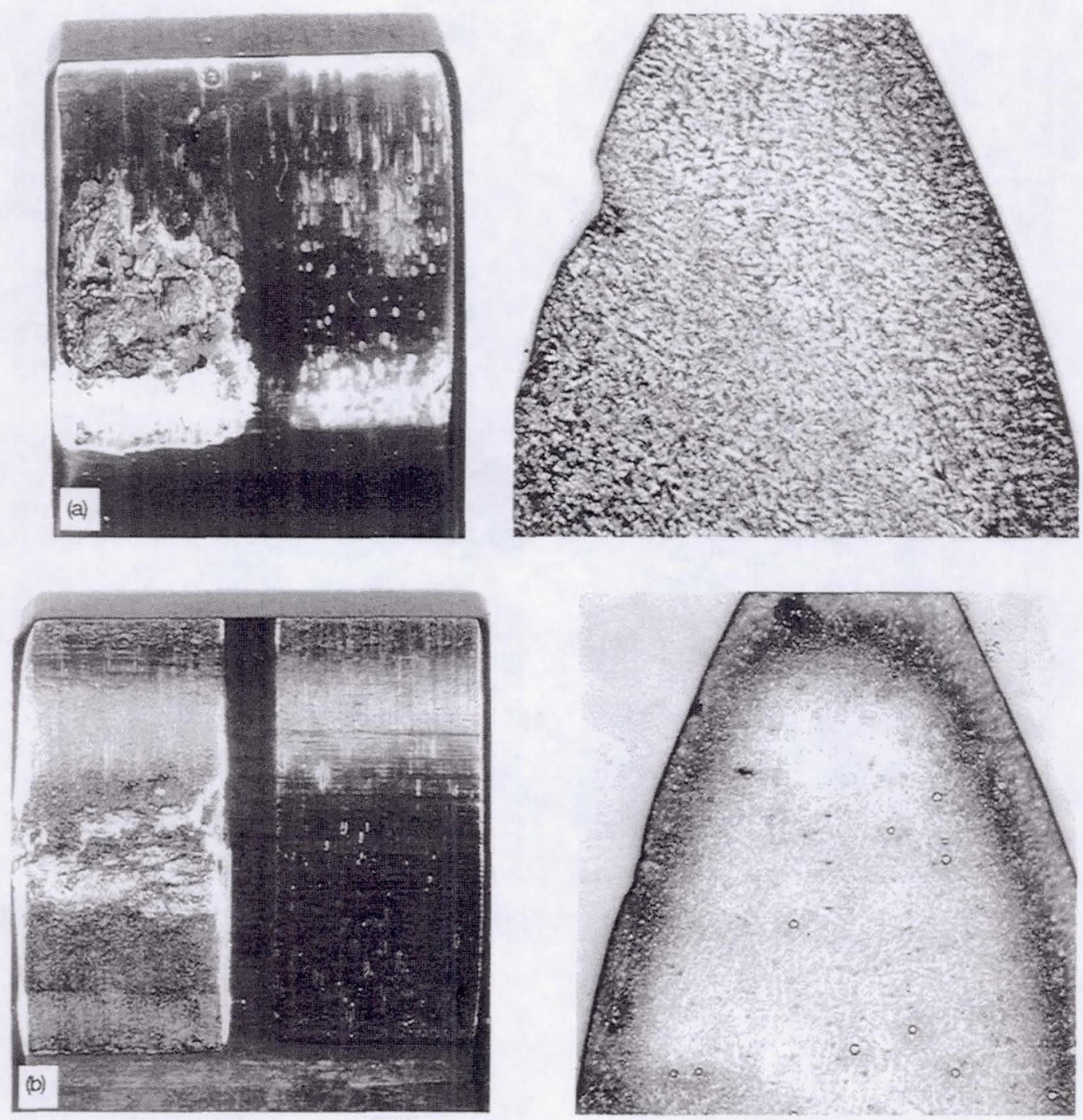

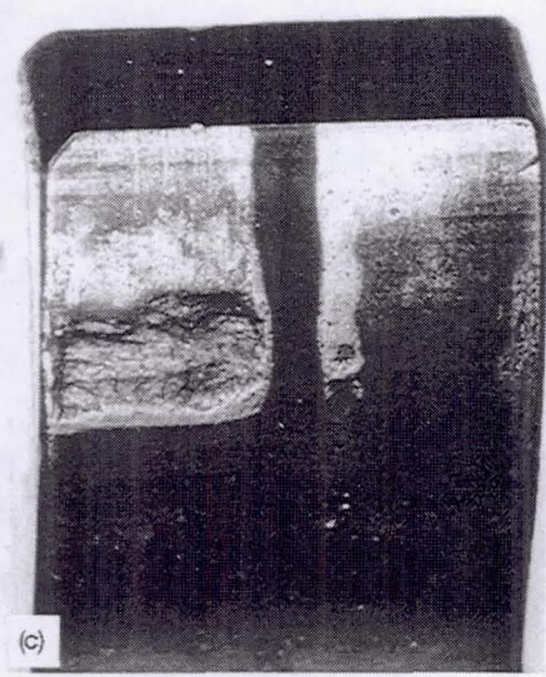

Fatigue spall

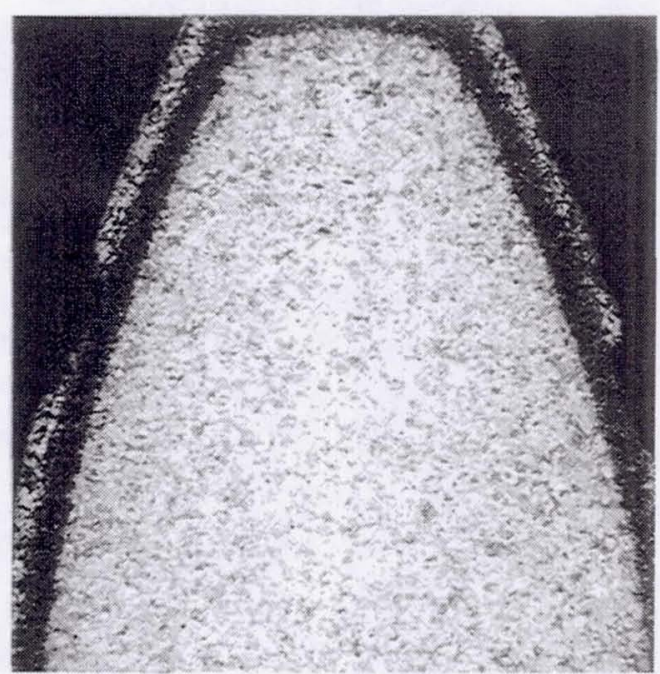

Cross section

Figure 5.-Typical fatigue spall and cross section of three high temperature gear materials. (a) VASCO Max 350. (b) VASCO Matrix II. (c) Nitralloy N. 


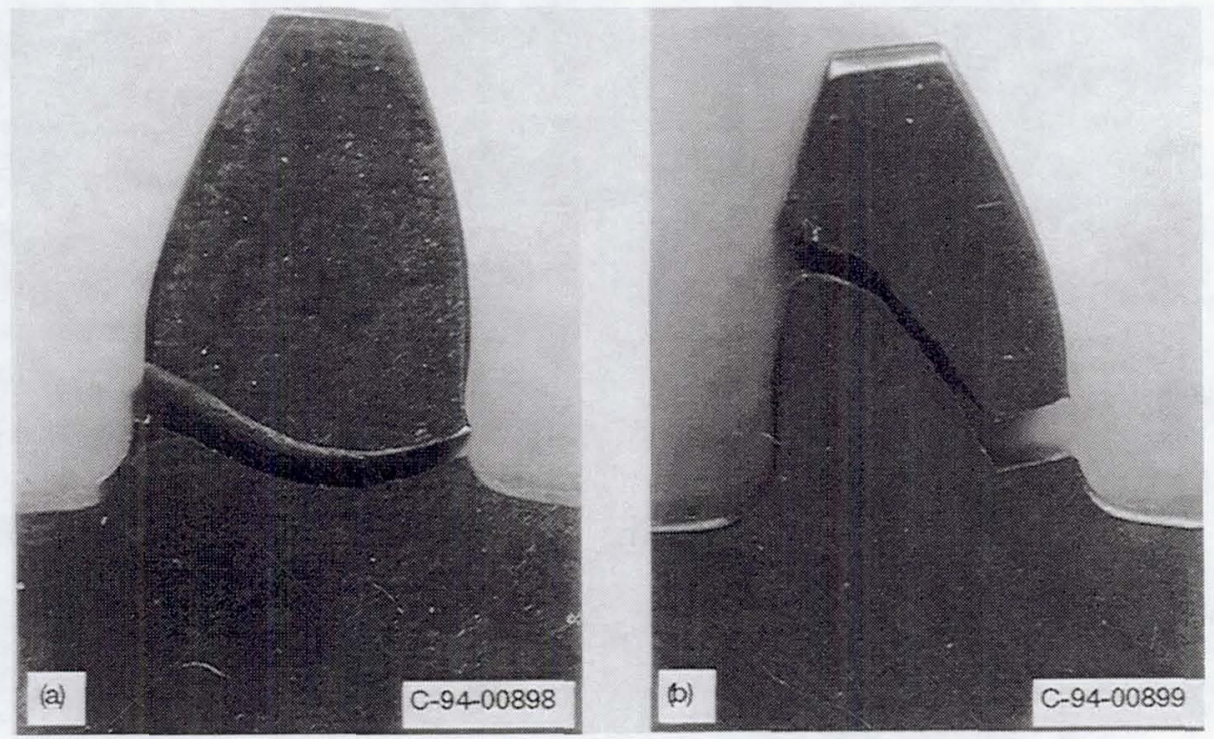

Figure 6.-Typical tooth fractures for two of the gear materials. (a) VASCO Max 350. (b) VASCO Matrix II. 
Public reporting burden for this collection of information is estimated to average 1 hour per response, including the time for reviewing instructions, searching existing data sources, gathering and maintaining the data needed, and completing and reviewing the collection of information. Send comments regarding this burden estimate or any other aspect of this Davis Highway, Suite 1204, Arlington, VA 22202-4302, and to the Office of Management and Budget, Paperwork Reduction Project (0704-0188), Washington, DC 20503.

\begin{tabular}{|l|c|c|}
\hline 1. AGENCY USE ONLY (Leave blank) & $\begin{array}{r}\text { 2. REPORT DATE } \\
\text { April } 1994\end{array}$ & $\begin{array}{r}\text { 3. REPORT TYPE AND DATES COVERED } \\
\text { Technical Memorandum }\end{array}$ \\
\hline
\end{tabular}

4. TITLE AND SUBTITLE

5. FUNDING NUMBERS

Surface Fatigue Life of High Temperature Gear Materials

6. $\operatorname{AUTHOR}(\mathrm{S})$

Dennis P. Townsend

WU-505-62-36

$1 \mathrm{~L} 162211 \mathrm{~A} 47 \mathrm{~A}$

7. PERFORMING ORGANIZATION NAME(S) AND ADDRESS(ES)

NASA Lewis Research Center

Cleveland, Ohio 44135-3191

and

Vehicle Propulsion Directorate

U.S. Army Research Laboratory

Cleveland, Ohio 44135-3191

9. SPONSORING/MONITORING AGENCY NAME(S) AND ADDRESS(ES)

National Aeronautics and Space Administration

Washington, D.C. 20546-0001

and

U.S Army Research Laboratory

Adelphi, Maryland 20783-1145

8. PERFORMING ORGANIZATION REPORT NUMBER

E-8738

11. SUPPLEMENTARY NOTES

Prepared for the 30th Joint Propulsion Conference cosponsored by the AIAA, ASME, SAE, and ASEE, Indianapolis, Indiana, June 27-29, 1994. Responsible person, Dennis P. Townsend, organization code 2730, (216) 433-3955.

\begin{tabular}{l|l} 
12a. DISTRIBUTION/AVAILABILITY STATEMENT & 12b. DISTRIBUTION CODE
\end{tabular}

Unclassified - Unlimited

Subject Category 37

13. ABSTRACT (Maximum 200 words)

Three high temperature gear materials were evaluated using spur gear surface fatigue tests. These materials were, VASCO max 350, VASCO matrix II, and nitralloy $\mathrm{N}$ and were evaluated for possible use in high temperature gear applications. The fatigue life of the three high temperature gear materials were compared with the life of the standard AISI 9310 aircraft gear material. Surface fatigue tests were conducted at a lubricant inlet temperature of $321 \mathrm{~K}\left(120^{\circ} \mathrm{F}\right)$, a lubricant outlet temperature of $350 \mathrm{~K}\left(170^{\circ} \mathrm{F}\right)$, a maximum Hertz stress of $1.71 \mathrm{GPa}(248 \mathrm{ksi})$, a speed of $10000 \mathrm{rpm}$ and with a synthetic paraffinic lubricant. The life of the nitralloy $\mathrm{N}$ was approximately the same as the AISI 9310 , the life of the VASCO max 350 was much less than the AISI 9310 while the life of the VASCO matrix II was several times the life of the AISI 9310 . The VASCO max 350 also showed very low fracture toughness with approximately half of the gears failed by tooth fracture through the fatigue spall. The VASCO matrix II had approximately 10 -percent fracture failure through the fatigue spalls indicating moderate to good fracture toughness.

\section{SUBJECT TERMS}

Gears; Fatigue; High temperature material

\begin{tabular}{c|c|c|c|}
\hline $\begin{array}{c}\text { 17. SECURITY CLASSIFICATION } \\
\text { OF REPORT } \\
\text { Unclassified }\end{array}$ & $\begin{array}{c}\text { 18. SECURITY CLASSIFICATION } \\
\text { OF THIS PAGE } \\
\text { Unclassified }\end{array}$ & $\begin{array}{c}\text { 19. SECURITY CLASSIFICATION } \\
\text { OF ABSTRACT } \\
\text { Unclassified }\end{array}$
\end{tabular}

